\title{
Use of Systemic Acquired Resistance and Whitefly Optical Barriers to Reduce Tomato Yellow Leaf Curl Disease Damage to Tomato Crops
}

\author{
Francisco Monci, Susana García-Andrés, Sonia Sánchez-Campos, Rafael Fernández-Muñoz, Juan Antonio Díaz-Pendón, and \\ Enrique Moriones ${ }^{\dagger}$
}

Instituto de Hortofruticultura Subtropical y Mediterránea "La Mayora", Universidad de Málaga-Consejo Superior de Investigaciones Científicas (IHSM-UMA-CSIC), Estación Experimental "La Mayora”, E-29750 Algarrobo-Costa, Málaga, Spain

\begin{abstract}
Epidemics of tomato yellow leaf curl disease (TYLCD) caused by tomato yellow leaf curl-like begomoviruses (genus Begomovirus, family Geminiviridae) severely damage open field and protected tomato crops worldwide. Intensive application of insecticides against the whitefly vector Bemisia tabaci is generally used as control strategy to reduce TYLCD impact. This practice, however, is frequently ineffective and has a negative impact on the environment and human health. TYLCD-resistant varieties are commercially available, but cultivation of susceptible traditional tasting ones is also requested if possible. For susceptible tomatoes, here we show that using whitefly

optical barriers by means of UV-blocking plastics in protected crops can contribute to reducing TYLCD damage and increasing commercial fruit yield. Moreover, induction of systemic acquired resistance by application of the elicitor of plant defense acibenzolar- $S$ methyl was effective to reduce yield losses when viral pressure was moderate. Interestingly, combining both practices in protected tomato crops can result in a significant TYLCD control. Therefore, these control practices are proposed to be used commercially as management alternatives to include in integrated management of TYLCD.
\end{abstract}

The tomato yellow leaf curl disease (TYLCD) causes severe damage to tomato (Solanum lycopersicum L.) production worldwide (Hanssen et al. 2010). A complex of phylogenetically related begomoviruses (genus Begomovirus, family Geminiviridae) that produce similar symptoms when they infect tomato plants has been associated with TYLCD (Moriones and Navas-Castillo 2010). To date, isolates of at least 10 different begomovirus species have been officially recognized as associated with TYLCD (Brown et al. 2015), among them isolates of tomato yellow leaf curl virus (TYLCV), one of the top 10 damaging viruses worldwide (Scholthof et al. 2011). TYLCD-associated viruses are transmitted in nature by the whitefly (Hemiptera: Aleyrodidae) vector Bemisia tabaci (Gennadius) in a persistent circulative manner (Cohen and Antignus 1994). Symptoms of the disease consist of yellowing, upward curling of leaflet margins, reduced size of apical young leaves, and plant stunting. Fruits are asymptomatic but reduced in size, making them unmarketable. Also, fruit numbers are reduced because of compromised flower set, with $100 \%$ yield loss observed when infections occur at early growth stages (Moriones and Navas-Castillo 2010).

Acceptable control of damage caused by TYLCD-associated viruses is achieved by using tomato varieties that incorporate virus resistance (Lapidot et al. 2014). Nevertheless, it should be taken into

Current address of F. Monci and S. García-Andrés: Monsanto Agricultura España, S.L. Paraje La Cumbre, s/n .04700 El Ejido, Almería, Spain.

${ }^{\dagger}$ Corresponding author: E. Moriones; moriones@eelm.csic.es

Funding: EM was supported by grant AGL2016-75819-C2-2-R and RF-M by grant AGL2015-65246-R, funded by the Ministerio de Economía, Industria y Competitividad, Spain, with assistance from the European Regional Development Fund (ERDF) and the European Social Fund (ESF). S. S.-C., F. M., and S. G.-A. were recipients of Ph.D. fellowships from the Ministerio de Educación y Ciencia, Spain (cofinanced by ERDF).

*The $\boldsymbol{e}$-Xtra logo stands for "electronic extra" and indicates that two supplementary tables are published online.

Accepted for publication 12 December 2018.

(c) 2019 The American Phytopathological Society account that some of the resistances can collapse under early and severe infection pressure (Polston and Lapidot 2007), as observed for the resistance most widely used commercially ( $T y-1$ resistance) (Michelson et al. 1994). In susceptible tomato varieties such as traditional tasting ones, control is mostly based on intensive insecticide applications to eliminate whiteflies and reduce virus spread. Chemical control of B. tabaci populations to reduce virus transmission, however, is largely ineffective, and will be more complicated in the near future due to the ban of many active ingredients of pesticides. Moreover, frequent insecticide application causes concerns because of negative environmental effects and development of resistant B. tabaci populations (Horowitz et al. 2007). Therefore, in regions where TYLCD is endemic, the absence of effective control measures has restricted production of susceptible tomato varieties to diseasefree periods.

Efforts to develop alternative and more sustainable control approaches to limit TYLCD damage in tomato have been made. In protected crops, the alternative of reducing vector entry by using 50-mesh nets in greenhouse openings can be implemented, but the resulting increased temperature and humidity can compromise crop production (Polston and Lapidot 2007). Also, the use of ultraviolet (UV)-blocking plastic sheets or nets in protected crops disturbing B. tabaci has been proposed and demonstrated to be effective under experimental conditions, in walk-in tunnels (Antignus 2010, 2014). The performance of UV-blocking plastics, however, to control TYLCD under commercial greenhouse conditions is unknown. This is especially important for the low-technified greenhouses typically used in Mediterranean regions, with large lateral windows only covered by nets opened most of the time. Induction of plant resistance by chemical activators (systemic acquired resistance [SAR]) is another environmentally friendly alternative for field management of plant diseases (Oostendorp et al. 2001; Shang et al. 2011; Sticher et al. 1997). The use of elicitors of SAR has been proposed as a challenging approach for crop protection and a possible and/or complementary alternative to manage virus infections in crops (Faoro and Gozzo 2015; Palukaitis et al. 2017; Vallad and Goodman 2004). SAR mechanisms operating against viruses are diverse, and may inhibit virus replication as well as cell-to-cell and long-distance movement; inhibition is often mediated by salicylic acid, which may also stimulate plant defense pathways related to RNA silencing (Faoro and Gozzo 2015; Palukaitis et al. 2017). Induced resistance has 
advantages for controlling viruses because no agrochemicals analogous to fungicides or bactericides exist that can be used to prevent virus diseases under field conditions. Benzothiadiazoles, among them acibenzolar- $S$-methyl (ASM), have been shown to aid in protection of plants by SAR and modulation of plant hormone signaling pathways that are crucial in disease and defense (RobertSeilaniantz et al. 2011). ASM is a synthetic analog of salicylic acid that is used commercially due to its reduced phytotoxicity and demonstrated effectiveness as activator of acquired resistance in several plant species including tomato (Friedrich et al. 1996; Gorlach et al. 1996; Herman et al. 2008; Katz et al. 1998; Lawton et al. 1996). ASM applications have been shown to be effective against a number of fungal and bacterial diseases in numerous hosts (Benhamou and Belanger 1998; Eikemo et al. 2003; Huang et al. 2012; Oostendorp et al. 2001; Radhakrishnan et al. 2011). Nevertheless, the use of plant activators for virus control has been given much more limited attention, although promising results have been obtained for some virus systems (Faoro and Gozzo 2015; Mandal et al. 2008; Momol et al. 2004; Murphy et al. 1999; Palukaitis et al. 2017; Riley et al. 2012; Takeshita et al. 2013). Scarce information is available about their possible use to control TYLCD, with no consistent results obtained (Fanigliulo et al. 2006; Sirigu et al. 2009).

Bearing in mind the above indicated difficulties in controlling TYLCD in open field and protected tomato crops, results are provided here that demonstrate the benefits of using strategies with limited environmental impact such as induction of resistance in plants or the use of UV-blocking plastic films as a whitefly optical barrier to reduce crop damage. Interestingly, the combination of both management strategies in greenhouse protected crops has been very promising, resulting in significantly increased TYLCD control. Therefore, these practices have great potential for inclusion as components in integrated TYLCD management programs.

\section{Materials and Methods}

Greenhouse and open field trials. Trials were conducted under natural TYLCD infection conditions in Málaga (Mediterranean coastal area of southern Spain). Independent trials (summarized in Supplementary Table S1) were conducted at sea level during the summer/early autumn period, when high TYLCD pressure occurs, in open field (Trials 1 and 2) or greenhouse protected (Trials 5 and 6 ) conditions. Also, two trials were conducted under moderate to low TYLCD disease pressures, one in open field during summer/ early autumn but in a region at $200 \mathrm{~m}$ above sea level (Trial 3) and another in a greenhouse at sea level but during the spring (Trial 4). Trials were performed in three consecutive years (Trial 1 in year 1 , Trials 2 to 5 in year 2, and Trial 6 in year 3) when TYLCD epidemics were the only ones observed in tomato crops.

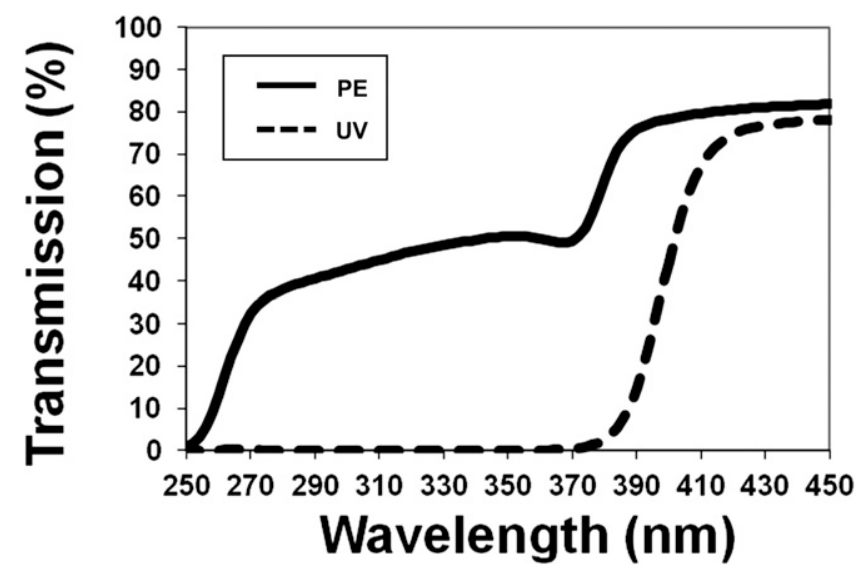

Fig. 1. Spectral transmission of plastic covers used in greenhouses. Spectral transmission of standard polyethylene (PE) Alcudia CP-2131P (PE, non-UVblocking) and PE Alcudia 2704FM (UV, UV-blocking) plastic films used as greenhouse covers in protected tomato crop trials; measures are shown between 250 and $450 \mathrm{~nm}$, comprising the UV light region, where differences are observed.
Protected crop trials were performed in typically low technified 'parral' type commercial greenhouses (Almeria type) $(50 \times 30 \mathrm{~m}$ in Trials 4 and 5; $12 \times 45 \mathrm{~m}$ in Trial 6). In these greenhouses, large open windows are present throughout the entire lateral length, covered with plastic nets with mesh sizes that allow ventilation and free movement of $B$. tabaci. In order to test the UV-blocking effect, the greenhouses were divided into two sectors, one covered with standard polyethylene (PE) plastic and the second with PE plastic with a UV-blocking additive. Both sectors were separated by a standard PE plastic wall to avoid whitefly exchanges between them. In Trial 6, designed to study the combined effects of standard PE or UVblocking plastics and ASM, each sector was divided into two blocks in which ASM or mock treatments were applied (see below for details). Numbers of plants per plastic cover treatment (standard or UV-blocking PE) were 200, 390, and 350 in Trials 4 to 6, respectively.

In open field trials (Trials 1 to 3 ), four treatments were performed (i, mock control; ii, standard insecticide; iii, ASM; and iv, ASM plus insecticide) in four randomized blocks. Each block consisted of four experimental plots, one for each treatment, with 48 (Trials 1 and 2) or 24 plants (Trial 3) per plot.

TYLCD-susceptible tomato plants of cv. Rambo (Syngenta Seeds, Switzerland) and cv. Carolina (Hazera, Israel) were used in protected and open field trials, respectively. In open field trials, two border lines of tomato plants of the TYLCD-susceptible cv. Daniela (Hazera, Israel) were planted per plot. In all cases, tomato plantlets were produced in an insect-free greenhouse and transplanted at the four leaves growth stage. Fertilization and crop management was done according to standard practices of local growers. Standard commercial insecticide control programs were conducted with applications at weekly intervals except for untreated control plots. Also, for ASM treatments, no insecticide application was done until 1 week after the last ASM application (see below). Hormonal applications were done during flowering for fruit setting in all cases.

Plant activator. The commercial product Bion 50WG (Syngenta Crop Protection, Switzerland) formulated with 50\% ASM as the active ingredient (a.i.) in water dispersible granules was used for SAR induction. ASM was applied at $2.5 \mathrm{~g}$ a.i./hl by foliar spraying to run-off using a hand-held sprayer. ASM requires approximately 4 days to activate plant defenses before systemic resistance is functional (Benhamou and Belanger 1998). Also, Syngenta recommends repeating applications every 10-15 days to maintain SAR activation, with no more than 4-5 applications per tomato crop to avoid unwanted residual product in tomato fruits. Therefore, in order to protect the tomato plants during initial growth stages when they are more susceptible to viral infection, two ASM applications were given to plants at the nursery stage, at 7 and 3 days before transplanting, and then three additional applications were given after transplanting, at 7- to 10-day intervals between applications. During trials using ASM applications, no unwanted phytotoxic effects were observed in tomato plants at the dose and frequencies used. Water spraying was used in mock control treatment.

Plastic covers. Greenhouse covers consisted of $0.2 \mathrm{~mm}$ thick PE plastic films with equivalent mechanical characteristics but differing in their optical properties for UV light transmission: the standard PE Alcudia CP-2131P (non-UV-blocking) and PE Alcudia 2704FM (UV-blocking) plastic films, both provided by Repsol (Madrid, Spain). The UV-blocking plastic totally blocks the transmission of wavelengths in the UV range (250-380 nm) (Fig. 1) without interfering with the transmission of the photosynthetically active radiation (PAR) (400-700 nm). The standard PE plastic used, as most greenhouse PE plastics commercialized, contains UV light-absorbing components to prolong the life of the material (Costa et al. 2002). Thus, this plastic blocks around 50\% of the UV light, as can be observed in the spectral transmission graphic (Fig. 1). Spectral transmission measures were made using a LI-1800 portable spectroradiometer (Li-Cor, U.S.A.).

TYLCD and associated virus, B. tabaci population, and yield assessments. TYLCD assessment was done by weekly observation of plants for disease symptom presence. Symptom severity ratings were given according to an arbitrary 0 to 5 scale where 
0 was assigned to asymptomatic plants and 5 was assigned to the severest TYLD symptoms. Also, TYLCD-associated virus presence was analyzed in plants by tissue blot hybridization with a mixture of probes that recognizes all the TYLCD-causing viruses present in Spain, according to Navas-Castillo et al. (1999). Four groups of plants per treatment were analyzed, avoiding border plants. Groups in open field trials corresponded to each treatment replicate and in greenhouse trials were located uniformly distributed in the surface of each treatment. For visual assessment, the number of plants per group varied from 48 (Trials 1 and 2) to 24 (Trial 3) plants in open field trials, and from 90 (Trial 5) to 40 (Trials 4 and 6) plants in protected crop trials. For hybridization analysis, 10 and 24 plants per group were analyzed in protected and open field trials, respectively. Complete correspondence between presence of TYLCD symptoms and positive hybridization results was found. Plants of each analyzed group were kept constant during the data collection period in every trial. Incidence data at each sampling date corresponded to the average value of the four groups analyzed.

Dynamics of B. tabaci populations were monitored from transplant to the end of the trial by two methods. For method one (used in greenhouse trials), yellow sticky traps (Horiver, Koppert, The Netherlands) (10 by $12 \mathrm{~cm}$ ), were used to estimate the whitefly population level present. Six traps per treatment were distributed uniformly in the assay avoiding border area and replaced weekly, adjusting them to the crop height. Also, six additional traps per treatment were distributed uniformly in the border area of the greenhouse, close to the lateral window openings. The number of adult $B$. tabaci individuals per trap was counted under a magnifying glass. For method two (used in greenhouse and open field trials), the number of adult B. tabaci per plant was counted in situ on nine leaflets (or one leaflet per leaf at early growth stages, selecting leaflets uniformly distributed in the plant) of 10 plants per treatment randomly chosen every week, avoiding border plants. The average number of whiteflies per trap or per leaflet was calculated for each date, and cumulative values were calculated to estimate whitefly pressure during the growth period.

Tomato yields were deduced from fruits collected in four groups of plants per treatment corresponding to the four replicated plots in open field trials and distributed uniformly in each treatment in greenhouse trials, avoiding border plants in both cases. Numbers of plants per group were 12,12, and 6 for open field Trials 1 to 3, respectively, and 15,16 , and 40 for greenhouse Trials 4 to 6 , respectively. At each harvest date, total commercial yield was obtained for each group of plants and yield per plant was deduced.

Data were analyzed using the IBM SPSS Statistics v. 24 software package by analysis of variance (ANOVA). The significance of
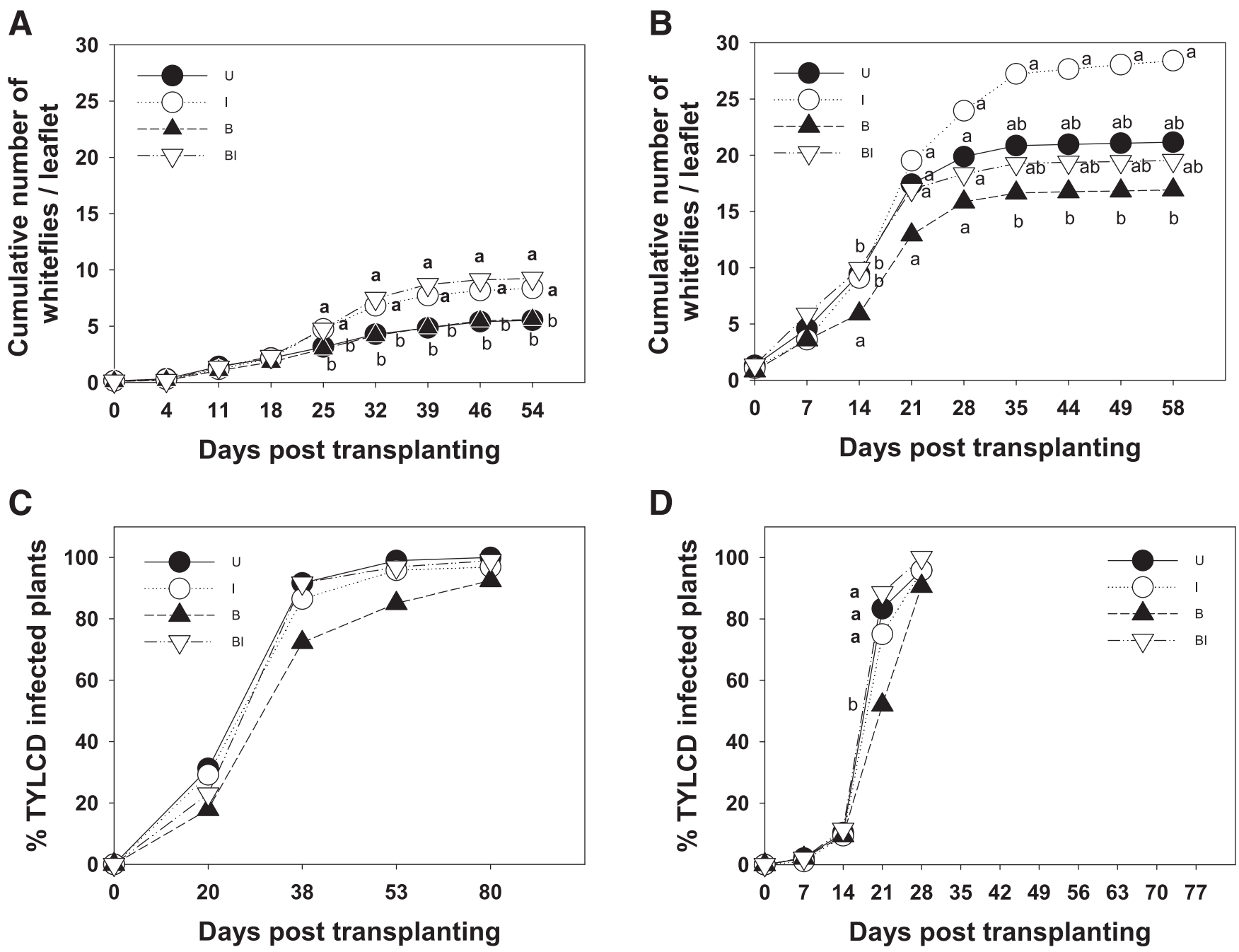

Fig. 2. Bemisia tabaci whitefly population numbers and tomato yellow leaf curl disease (TYLCD) incidence in open field tomato trials. B. tabaci infestation and TYLCD incidence at several days post transplanting (dpt) in open field tomato crop Trial 1 (A, C) and Trial 2 (B, D). Treatment means are represented for cumulative numbers of $B$. tabaci adults counted on tomato leaflets (A, B), and for percentage of plants infected with TYLCD-associated virus detected by tissue-blot hybridization (C, D). Treatments are: U, untreated control; I, regular insecticide control; B, Bion 50WG (50\% acibenzolar-S-methyl, ASM); BI, Bion plus insecticide. Mean values in different treatments sharing a common letter in the same date are not significantly different at $P \leq 0.05$ (Bonferroni-corrected contrast tests under GzLM analysis using Log $(x+1)$ as the link function and Poisson as the probability distribution for numbers of whiteflies; or using Logit as the link function and Binomial as the probability distribution for relative frequency of virus-infected plants), with letters shown only when differences are detected. 
means differences was assessed by Fisher's least significant difference (LSD) test when normally distributed parametric data were analyzed or by the generalized linear model (GzLM) with the appropriate probability distribution and link function and treatments compared by paired or multiple contrasts corrected by sequential Bonferroni tests when non-parametric or non-normally distributed data were analyzed.

\section{Results}

ASM application results in reduced TYLCD damage in open field tomato crops with moderate infection pressure. For the two open field trials conducted in the area where high TYLCD pressure usually occurred (Trials 1 and 2), noticeable differences were observed in whitefly population numbers and TYLCD incidence. Thus, as shown in Figure 2, higher whitefly population numbers (compare Fig. 2B and 2A) and TYLCD incidence (compare Fig. $2 \mathrm{D}$ and $2 \mathrm{C}$ ) were observed in Trial 2 than in Trial 1. Disease progress curves show that under these conditions, control measures were

A

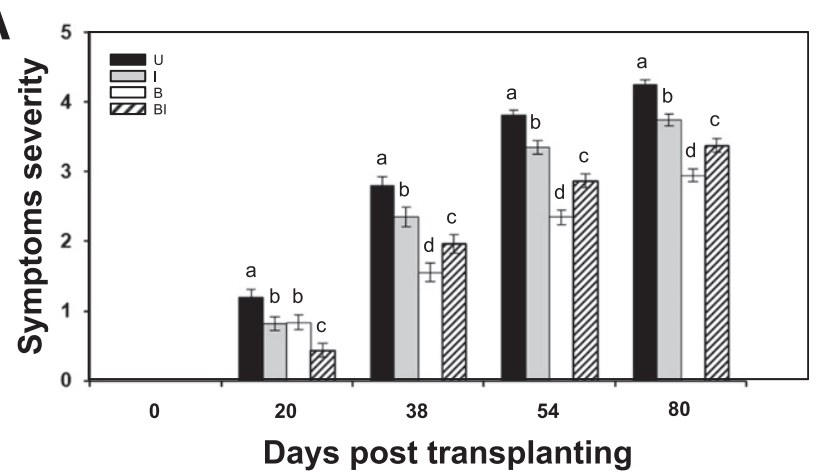

B
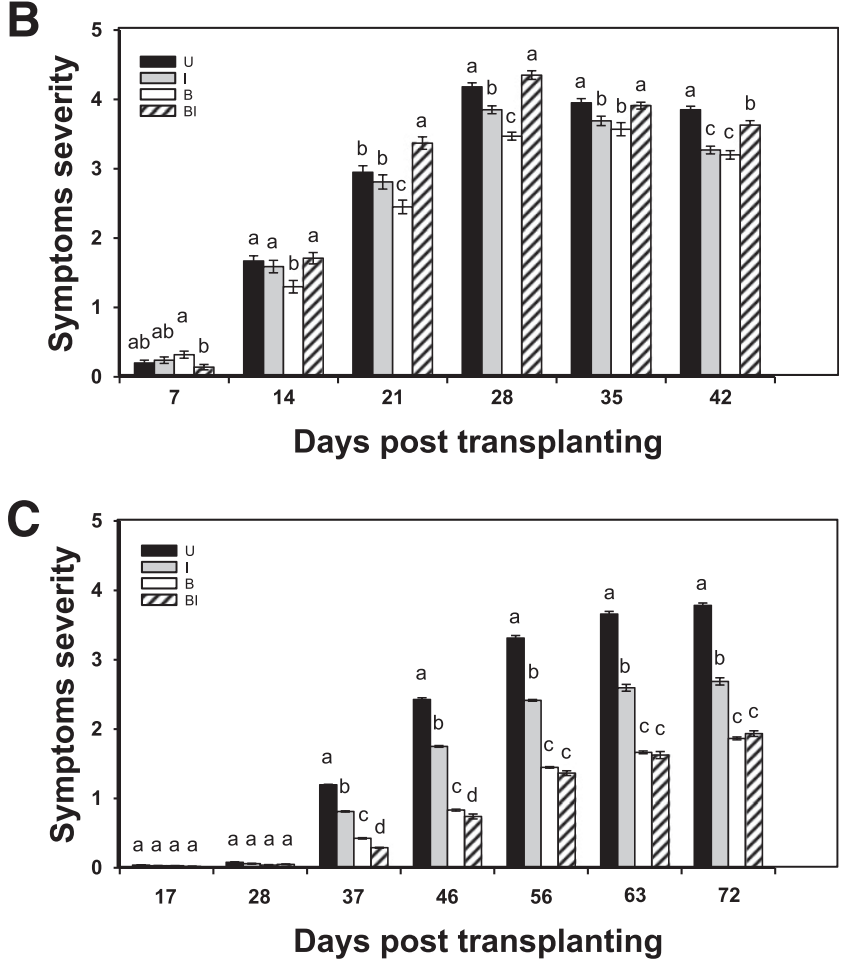

Fig. 3. Tomato yellow leaf curl disease (TYLCD) symptom severity on tomato plants of open field tomato trials. TYLCD symptoms' severity at several days post transplanting on tomato plants of open field crops conducted in Trials 1 to 3 (A, B, and C, respectively). Symptom severity ratings were given according to an arbitrary 0 to 5 scale where 0 was assigned to asymptomatic plants and 5 was assigned to the severest TYLCD symptoms. Treatment means are represented for the following treatments: U, untreated control; I, regular insecticide; B, Bion 50WG $(50 \%$ acibenzolar-S-methyl, ASM); BI, Bion plus insecticide. Values in different treatments sharing a common letter in the same date are not significantly different at $P \leq 0.05$ (one-way ANOVA/LSD test); bars indicate standard error of the mean unable to reduce TYLCD incidence, with incidences above $70 \%$ after 38 (Fig. 2C) or 28 (Fig. 2D) days post transplanting (dpt). Interestingly, however, significantly less severe TYLCD symptoms were observed in most sampling dates for plants treated only with ASM (Fig. $3 \mathrm{~A}$ and $3 \mathrm{~B}$ ), especially when disease pressure was not extreme (Fig. $3 A)$. Notice that higher whitefly numbers were observed for treatments including insecticide applications either alone or combined with ASM (I and B+I, Fig. 2A and 2B). The latter was associated with the deleterious effects of insecticides on populations of natural enemies of B. tabaci (personal observation).

For the open field trial conducted in an area in which lower TYLCD pressure usually occurred (Trial 3), maximum TYLCD incidences below $80 \%$ were attained at the end of the crop (data not shown). Interestingly, under these less aggressive conditions, the reduced TYLCD severity observed in plants treated with ASM was significant even for treatments including insecticide applications (Fig. 3C). As a result, significantly increased commercial tomato yields were obtained in ASM-treated plants in Trial 3 (Table 1).

Use of UV-blocking plastic covers in greenhouse tomato crops reduces $B$. tabaci populations and TYLCD incidence and damage. As expected for spring conditions, very low whitefly infestation occurred in Trial 4 conducted in greenhouse, whether under the UV-blocking or the standard PE plastics. Consequently, no TYLCD infections were observed that allowed us to evaluate the possible effect of UV-blocking in tomato plant growth and/or yield. No significant differences were observed between plants grown under UV-blocking or standard PE plastics in the variables evaluated per plant (number of flower clusters set, amount of commercial fruits, total commercial tomato yield, fresh weight of the plant at the end of the harvesting period) (Supplementary Table S2). Therefore, the use of UV-blocking plastic covers had no effect on tomato growth and yield, and the experimental study continued.

During Trial 5 in greenhouse and summer conditions, very high $B$. tabaci population numbers were detected from the beginning of the crop. Interestingly, significant differences in whitefly numbers within the crop either captured in traps or counted on plants were observed between treatments, with lower whitefly pressure under the UV-blocking plastic (Fig. 4A and 4B). Also, a similar trend was observed for whiteflies captured in traps located in border lines (Fig. 4C), suggesting that a significantly lower tendency of $B$. tabaci to enter into the UV-blocking plastic crop area had occurred. Nevertheless, adult whiteflies were present under the UV-blocking plastic in numbers that could be enough to efficiently spread TYLCD. The results showed, however, that significantly lower TYLCD incidence occurred under the UV-blocking plastic compared with standard PE plastic. Differences in TYCLD incidence close to $50 \%$ were observed at the end of the crop (Fig. 4D) with very low TYLCD incidence under the UV-blocking plastic until about $60 \mathrm{dpt}$. Ripe tomato yield could be evaluated in this assay only from the first two flower clusters, because the crop was removed before production completion owing to space limitations. However, although no significant differences were observed for ripe tomatoes except that fruits under UV-blocking plastic were bigger (better commercial value), significantly higher yield was expected for plants under UVblocking plastic based on the significant differences observed for commercial size unripe tomatoes (Table 2). Thus, about $43 \%$ higher yield was expected under UV-blocking plastic compared with standard PE plastic (Table 2).

Beneficial combination of ASM application and UV-blocking film covers in greenhouse tomato crops to reduce TYLCD damage. As in previous assays (see above), decreased TYLCD incidence occurred in protected tomatoes when using UV-blocking plastic films, and beneficial ASM application effects were clearer when moderate TYLCD incidence occurred; the effect of the combination of both control strategies was studied in Trial 6. In this case, as in Trial 5, and as shown in Figure 5A for the incidence of symptomatic plants, a significantly lower level of TYLCD pressure occurred under UV-blocking plastics compared with that observed in standard PE ones. Interestingly, under these growth conditions, ASM application resulted in significantly reduced TYLCD 
incidences either combined with standard PE or UV-blocking plastics (Fig. 5A), with the lowest TYLCD incidences observed in the latter case. This resulted in significantly higher yields obtained in treatments using ASM or UV-blocking plastics alone or in combination (Table 3). Although not significantly different statistically, maximum yields were obtained combining ASM with UVblocking plastics. Similarly to Trial 5 , significantly lower whitefly population numbers were observed under UV-blocking plastics (Fig. 5B). Also, reduced whitefly population numbers were ob- served in treatments including ASM, which at least in part was associated with the lack of the deleterious effects of insecticides on populations of natural enemies of $B$. tabaci (personal observation).

\section{Discussion}

In this study, we present data showing the possibility of reducing TYLCD damage in tomato crops by induction of systemic acquired resistance in plants and the use of optical barriers to $B$. tabaci in

Table 1. Treatment mean ( \pm standard error) yields from open field tomato crops conducted in areas with high (Trials 1 and 2) or moderate (Trial 3) tomato yellow leaf curl disease (TYLCD) pressures

\begin{tabular}{|c|c|c|c|c|c|c|}
\hline \multirow[b]{2}{*}{ Treatmenty } & \multicolumn{2}{|r|}{ Trial 1} & \multicolumn{2}{|r|}{ Trial $2^{x}$} & \multicolumn{2}{|r|}{ Trial 3} \\
\hline & $\underset{\text { Yield }}{\text { (g)/plant }}$ & $\begin{array}{l}\text { Increased yield respect } \\
\text { to treatment } U(\%)\end{array}$ & $\begin{array}{c}\text { Yield } \\
\text { (g)/plant }\end{array}$ & $\begin{array}{c}\text { Increased yield respect to } \\
\text { treatment } U(\%)\end{array}$ & $\begin{array}{c}\text { Yield } \\
\text { (g)/plant }\end{array}$ & $\begin{array}{c}\text { Increased yield respect } \\
\text { to treatment } U(\%)\end{array}$ \\
\hline $\mathrm{U}$ & $1,024 \pm 15 b^{z}$ & - & $81 \pm 12 b$ & - & $975 \pm 20 \mathrm{c}$ & - \\
\hline I & $1,367 \pm 14 \mathrm{a}$ & 33.5 & $253 \pm 37 a$ & 213.1 & $1,449 \pm 27 b$ & 48.6 \\
\hline B & $1,525 \pm 29 a$ & 48.9 & $210 \pm 30 \mathrm{a}$ & 159.9 & $2,016 \pm 49 a$ & 106.8 \\
\hline BI & $1,626 \pm 19 \mathrm{a}$ & 58.8 & $326 \pm 47 \mathrm{a}$ & 303.6 & $2,070 \pm 39 \mathrm{a}$ & 112.4 \\
\hline
\end{tabular}

${ }^{x}$ During Trial 2, extremely severe TYLCD pressure occurred that resulted in a dramatic yield loss.

y (U) untreated control, (I) regular insecticide applications, (B) Bion 50WG (50\% acibenzolar-S-methyl) application, (BI) Bion plus insecticide applications

${ }^{\mathrm{z}}$ Mean values of different treatments sharing a common letter in the same column are not significantly different at $P \leq 0.05$ (one-way ANOVA/LSD test).

A

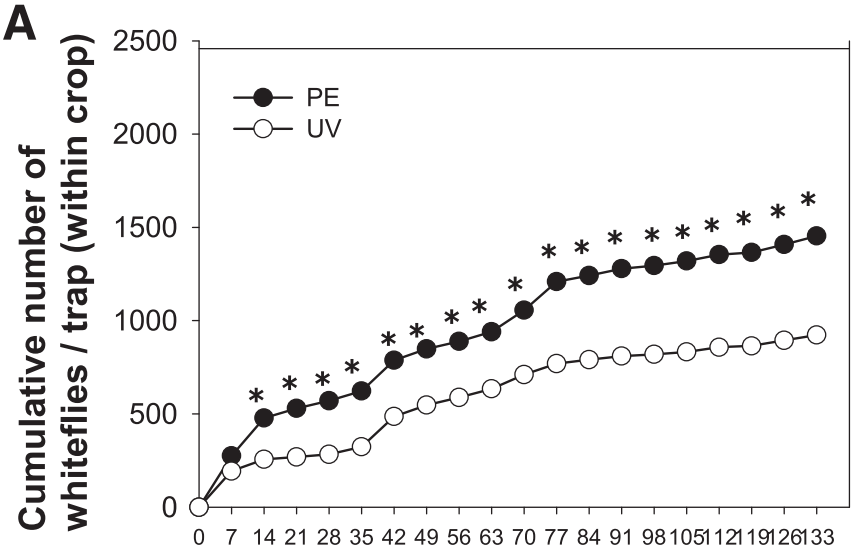

Days post transplanting
B

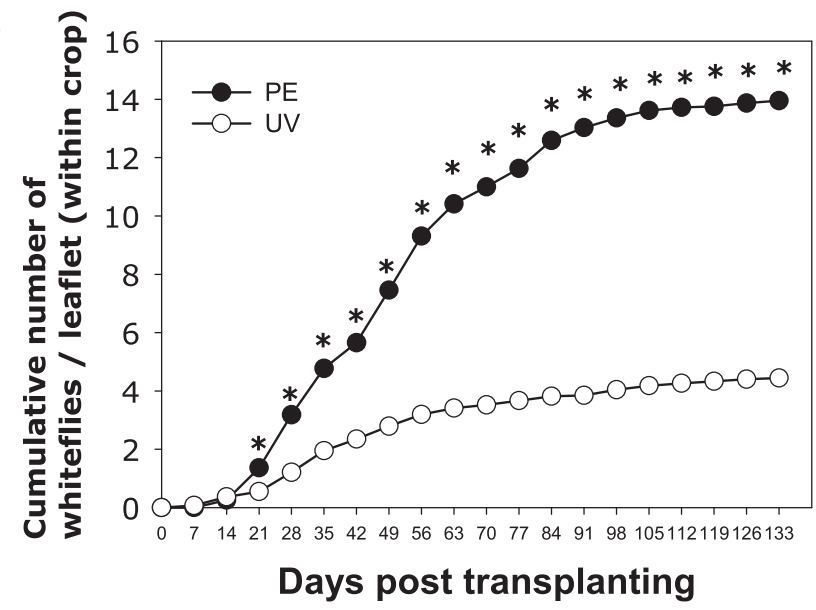

C

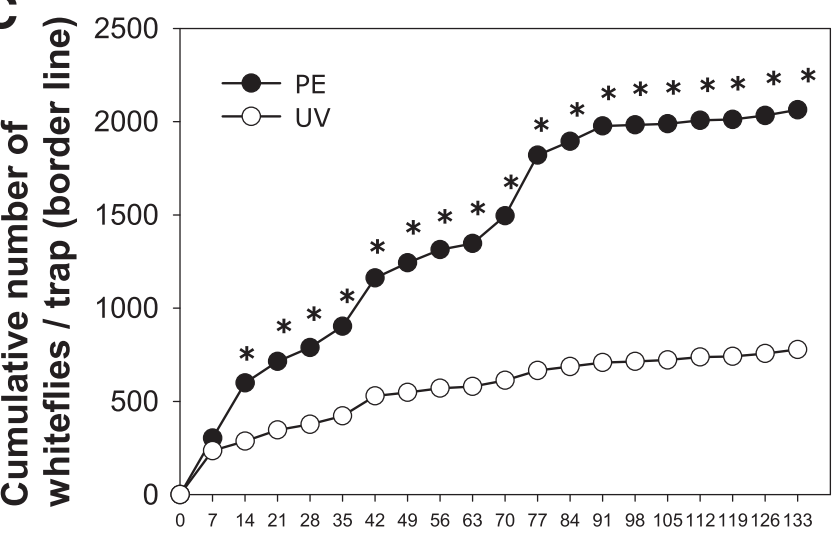

Days post transplanting

D

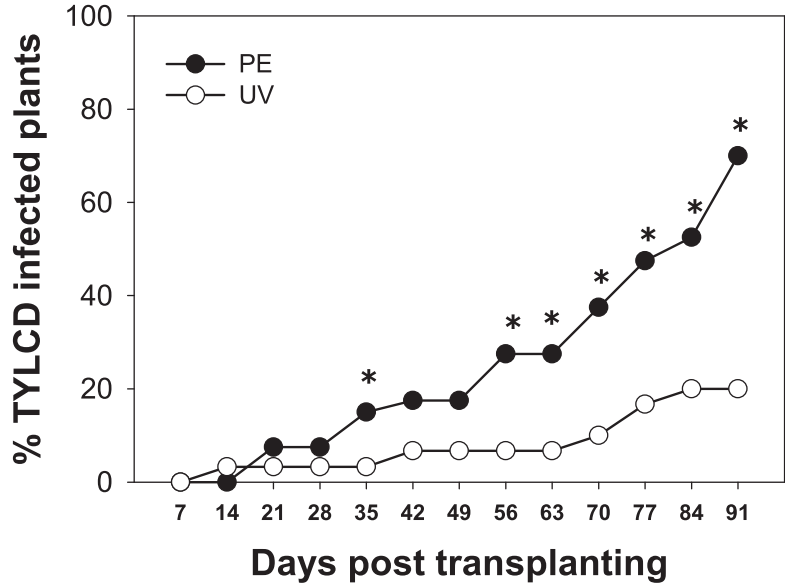

Fig. 4. Bemisia tabaci whitefly population numbers and tomato yellow leaf curl disease (TYLCD) incidence in greenhouse tomato trials. B. tabaci infestation and TYLCD incidence evaluated at several days post transplanting (dpt) in tomato crops grown under UV-blocking (UV) or standard (PE) polyethylene plastics in greenhouse Trial 5. Treatment means are represented for cumulative numbers of $B$. tabaci adults captured on yellow sticky traps placed within the crop (A) or at the border lines of the crop (C); or of adult $B$. tabaci individuals counted on tomato leaflets from plants within the crop (B). Also, means are represented for percentage of plants infected with TYLCD-associated virus detected by tissue-blot hybridization (D). Mean values in different treatments showing an asterisk in the same date are significantly different at $P \leq 0.05$ (Bonferroni-corrected contrast tests under GzLM analysis using Log $(x+1)$ as the link function and Poisson as the probability distribution for numbers of whiteflies; or using Logit as the link function and Binomial as the probability distribution for relative frequency of virus-infected plants). 
protected crops, thus providing additional management strategies. The high potential of these control practices when used at commercial-like level has been demonstrated here. Interestingly, the combination of both control strategies in greenhouse protected crops showed promising results, with synergistically increased TYLCD control. These strategies could be easily integrated in crop management programs for a more sustainable and effective control of TYLCD. TYLCD causes significant economic losses to tomato crops, with a continuous emergence worldwide (Hanssen et al. 2010; Lefeuvre et al. 2010; Moriones et al. 2011; Varma et al. 2011). Although commercial resistance exists (Lapidot et al. 2014), effective control is still a challenge, especially for high value susceptible varieties grown to produce tasting tomatoes. Moreover, the integration of control strategies such as those discussed here with resistance programs might help to increase the sustainability and durability of plant resistance to TYLCD-associated viruses by helping to reduce the intensity of epidemics (Fabre et al. 2012; Moury et al. 2011). Our results consistently support the benefits of using SAR through ASM applications to limit TYLCD impact under moderate TYLCD pressure in either open field or protected tomato crops leading to significantly increased yields. Although activation of plant defense has been cited that might result in reductions in growth and reproductive fitness of plants (Cipollini et al. 2003), in our experiments no evident detrimental effect of ASM was observed following the suggested application program. ASM is known to activate SARassociated genes in tomato (Achuo et al. 2004; Herman et al. 2008; Malolepsza 2006; Pradhanang et al. 2005), and reports are available for its ability to inhibit local (Anfoka 2000; Chivasa et al. 1997; Murphy and Carr 2002) and systemic (Ji and Ding 2001; Mandal et al. 2008; Naylor et al. 1998; Takeshita et al. 2013) accumulation of viruses belonging to different groups. Although the exact mechanism was not analyzed here, we showed that ASM applications contributed to reduce TYLCD-associated yield losses similarly to results obtained for the RNA virus tomato spotted wilt virus (TSWV) (Momol et al. 2004; Riley et al. 2012). It is worth mentioning, that similarly to our results, ASM-based control with this latter virus functioned better under lower disease pressures (Riley et al. 2012). The reduced TYLCD severity observed in ASM-treated plants could suggest virus infection impairment. Despite recent progress in the knowledge of SAR mechanisms, only a few compounds, including benzothiadiazole, have been shown to reduce the severity of systemic virus disease (Faoro and Gozzo 2015; Palukaitis et al. 2017). In fact, ASM is a synthetic analog of salicylic acid which has been reported to be involved in virus infection modulation (Zhu et al. 2014). Nevertheless, it cannot be ruled out that some effect might have occurred on $B$. tabaci that could have contributed to reduce TYLCD disease pressure. Reports are available about the ability of ASM to contain insect populations in tomato plants such as for the whitefly $B$. tabaci (Nombela et al. 2005) or the aphid Myzus persicae (Boughton et al. 2006). Moreover, it was shown that the life history traits of $B$. tabaci were adversely affected on SA-treated plants (Shi et al. 2013). Therefore, this is an aspect that will need further study. Another beneficial effect of using ASM applications and reducing insecticide pressure in TYLCD management programs could be the reduction of the deleterious effects of the latter on $B$. tabaci natural enemies. Therefore, a more efficient natural biological control of $B$. tabaci could have contributed to reduce TYLCD pressure in plots treated only with ASM in our study. In fact, although not quantified, we observed higher population numbers of natural enemies in plots where insecticides were not used. Thus, the reduced $B$. tabaci population numbers observed in our trials in treatments including ASM might then be the result of

\section{A}

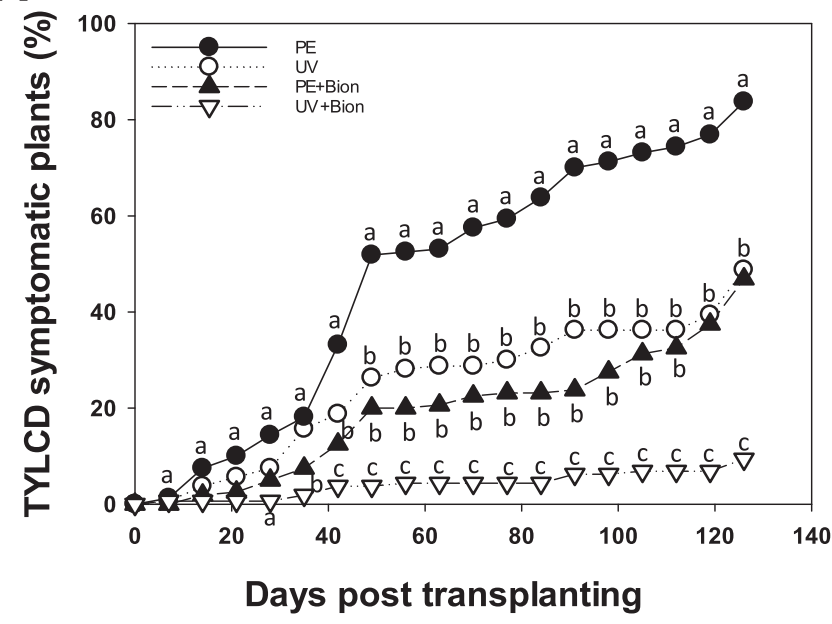

B

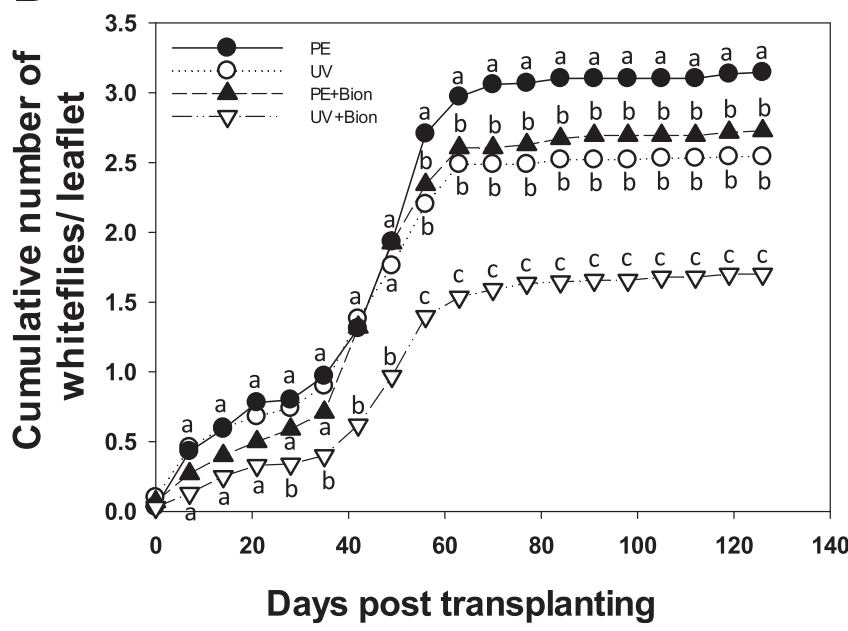

Fig. 5. Tomato yellow leaf curl disease (TYLCD) incidences and Bemisia tabaci whitefly population numbers in a greenhouse tomato trial combining UV-blocking plastics and induction of systemic acquired resistance. TYLCD incidences and $B$. tabaci infestation were evaluated at several days post transplanting (dpt) in a protected tomato crop Trial 6 conducted under UV-blocking (UV) or standard (PE) polyethylene plastics in combination with the inducer of systemic acquired resistance Bion 50WG (50\% acibenzolar-S-methyl, ASM). Treatment means are represented for percentage of plants exhibiting TYLCD symptoms (A) and for cumulative numbers of $B$. tabaci adults counted on tomato leaflets (B). Mean values in different treatments sharing a common letter in the same date are not significantly different at $P \leq 0.05$ (Bonferroni-corrected contrast tests under GzLM analysis using Logit as the link function and Binomial as the probability distribution for relative frequency of virus-infected plants, or using Log $(x+1)$ as the link function and Poisson as the probability distribution for numbers of whiteflies).

Table 2. Treatment mean ( \pm standard error) production values from a greenhouse tomato crop conducted in Trial 5, under UV-blocking (UV) or standard (PE) polyethylene plastics ${ }^{x}$

\begin{tabular}{|c|c|c|c|c|c|c|c|c|}
\hline \multirow[b]{2}{*}{$\begin{array}{l}\text { Plastic } \\
\text { cover }^{y}\end{array}$} & \multicolumn{4}{|c|}{ Commercial ripe tomato } & \multicolumn{4}{|c|}{ Commercial unripe tomato } \\
\hline & $\begin{array}{l}\text { No. fruits/ } \\
\text { plant }\end{array}$ & $\begin{array}{l}\text { Weight }(g) / \\
\text { fruit }\end{array}$ & $\begin{array}{l}\text { Yield }(\mathbf{g}) / \\
\text { plant }\end{array}$ & $\begin{array}{c}\text { Increased yield } \\
\text { respect to PE (\%) }\end{array}$ & $\begin{array}{l}\text { No. fruits/ } \\
\text { plant }\end{array}$ & $\begin{array}{c}\text { Weight }(\mathbf{g}) / \\
\text { fruit }\end{array}$ & $\begin{array}{l}\text { Yield }(\mathrm{g}) / \\
\text { plant }\end{array}$ & $\begin{array}{c}\text { Increased yield } \\
\text { respect to PE (\%) }\end{array}$ \\
\hline$\overline{\mathrm{PE}}$ & $2.4 \pm 0.1 \mathrm{a}^{\mathrm{z}}$ & $197.6 \pm 3.1 \mathrm{~b}$ & $480 \pm 22 a$ & - & $24.2 \pm 0.3 b$ & $86.2 \pm 1.5 \mathrm{~b}$ & $2,090 \pm 53 \mathrm{~b}$ & - \\
\hline UV & $2.3 \pm 0.1 \mathrm{a}$ & $226.1 \pm 5.3 \mathrm{a}$ & $526 \pm 28 \mathrm{a}$ & 9.8 & $27.7 \pm 0.4 \mathrm{a}$ & $106.9 \pm 2.3 \mathrm{a}$ & $2,993 \pm 101 \mathrm{a}$ & 43.2 \\
\hline
\end{tabular}

${ }^{\mathrm{x}}$ Commercial tomatoes from the first two flower clusters were harvested and at the same time, all commercial size unripe tomatoes were collected from other set flower clusters at 133 days post transplanting.

y Plastic covers: PE, standard polyethylene non UV-blocking plastic film; UV, UV-blocking plastic film.

${ }^{\mathrm{z}}$ Values of different treatments sharing a common letter in the same column are not significantly different at $P \leq 0.05$ (one-way ANOVA/LSD test). 
Table 3. Treatment mean ( \pm standard error) production values from a greenhouse tomato crop conducted in Trial 6 under UV-blocking (UV) or standard (PE) polyethylene plastics in combination with the elicitor of systemic acquired resistance acibenzolar- $S$-methyl (B)

\begin{tabular}{lccc}
\hline Treatment $^{y}$ & No. fruits/plant & Yield (g)/plant & Increased yield respect to PE (\%) \\
\hline PE & $17.1 \pm 0.2 \mathrm{c}^{\mathrm{z}}$ & $3,797 \pm 46 \mathrm{~b}$ & - \\
$\mathrm{UV}$ & $20.1 \pm 0.2 \mathrm{~b}$ & $4,705 \pm 63 \mathrm{a}$ & 23.9 \\
$\mathrm{PE}+\mathrm{B}$ & $21.9 \pm 0.2 \mathrm{ab}$ & $4,942 \pm 43 \mathrm{a}$ & 30.2 \\
$\mathrm{UV}+\mathrm{B}$ & $23.2 \pm 0.1 \mathrm{a}$ & $5,462 \pm 44 \mathrm{a}$ & 43.8 \\
\hline
\end{tabular}

y PE, standard polyethylene (PE) non-UV-blocking plastic film; UV, UV-blocking plastic film; B, Bion 50WG (50\% acibenzolar-S-methyl).

$\mathrm{z}$ Values of different treatments sharing common letters in the same column are not significantly different at $P \leq 0.05$ (one-way ANOVA/LSD test).

the indicated beneficial effects. It is interesting to note that our results suggested that under less aggressive disease pressure conditions, more effective contribution of ASM applications to TYLCD control was observed, leading to lower incidence and consequently to increased tomato yields.

Here, we also demonstrated that for protected crops, the use of UVblocking plastic films in low technified greenhouse commercial-like tomato crops can be a valuable alternative to reduce $B$. tabaci population numbers and TYLCD damage. The beneficial effect of UV manipulation for insect and vectored virus control has been proven (Antignus 2010, 2014; Costa et al. 2002; Díaz and Fereres 2007; Kumar and Poehling 2006; Mutwiwa et al. 2005). The ability of $B$. tabaci to reach the target plant was reduced by photoselective nets (Legarrea et al. 2012). However, at least for B. tabaci and TYLCD, to our knowledge conclusive studies in commercial size greenhouses are not available. Here we demonstrated that the use of UV-blocking plastic covers in greenhouse tomato production resulted into reduced $B$. tabaci populations and TYLCD buildup with increased tomato yields. These results scaled up results previously obtained in small experimental walk-in plastic tunnels (Antignus 2010) and further supports interest in using this approach at the commercial level. The optical disturbance effect of plastic films on whitefly dispersal was nicely demonstrated by Doukas and Payne (2007), who found significant dispersal reduction in ambience lacking UV light. As observed before (Antignus 2007), no significant effect was observed here of UV-blocking plastics on tomato growth or yield.

The possible effect of the use of UV-blocking plastics on the beneficial insects now popular for biological control in greenhouse tomato crops should also be taken into account. At least for bumblebees (Bombus sp.) used for pollination, it has been demonstrated that they can rapidly learn and adapt their visual system to forage efficiently in environments that exclude UV radiation (Dyer and Chittka 2004). Therefore, adequate management of bumblebee hives is possible to avoid adverse consequences (Antignus 2010). However, the effect of the use of UV-blocking plastic covers on the performance of beneficial insects used in biological control should also be evaluated for specific cases, as differences are observed depending on the specific insect (Antignus 2007; Chiel et al. 2006). Therefore, knowing the degree of compatibility between each biological control and the use of UV-blocking plastic covers will be crucial for successful pest management in protected crops using optical disturbance strategy (Legarrea et al. 2012).

It is noticeable that we found a significantly increased beneficial effect of reduced TYLCD damage in greenhouse tomato crops by combining UV-blocking plastics with ASM applications. Although this is an aspect that will need further demonstration, our results are very encouraging and suggested the potential of the integration of both control strategies in protected tomato crops. A similar beneficial effect also was suggested with the combination of ASM application with UV-reflective mulches or floating row covers for TYLCD management in greenhouse tomatoes (Sirigu et al. 2009). Also, ASM applications functioned better to reduce TSWV incidence when combined with the use of UV-reflective mulch to lower thrips populations (Riley et al. 2012). This increased control is congruent with the better performance observed here for ASM applications under reduced disease pressure.
Resistant cultivars for TYLCD control are increasingly used commercially (Lapidot et al. 2014). However, dependence on disease pressure has been reported, for example for the $T y-1$ gene widely used commercially against begomoviruses in tomatoes (Michelson et al. 1994). Therefore, under high TYLCD pressure, integration of management strategies such as those proposed here can significantly improve the performance of resistant cultivars. Also, reducing TYLCD incidence with these additional control strategies might help to increase the durability of resistance by reducing the risk of a rise of a resistance-breaking virus type in the population (Mundt et al. 2002). Therefore, the two alternatives for TYLCD management shown here are strongly recommended for integration with resistance deployment for a more durable TYLCD control.

\section{Acknowledgments}

We thank Enrique Espí and Antonio López for their contribution to the UVblocking plastic and ASM trials, respectively, and Carmen Soria (IFAPA, Málaga, Spain) for his help with greenhouse and open field trials.

\section{Literature Cited}

Achuo, E. A., Audenaert, K., Meziane, H., and Höfte, M. 2004. The salicylic aciddependent defence pathway is effective against different pathogens in tomato and tobacco. Plant Pathol. 53:65-72.

Anfoka, G. H. 2000. Benzo-(1,2,3)-thiadiazole-7-carbothioic acid S-methyl ester induces systemic resistance in tomato (Lycopersicon esculentum. Mill cv. Vollendung) to Cucumber mosaic virus. Crop Prot. 19:401-405.

Antignus, Y. 2007. The management of Tomato yellow leaf curl virus in greenhouses and the open field, a strategy of manipulation. Pages 263-278 in: Tomato Yellow Leaf Curl Virus Disease Management, Molecular Biology, Breeding for Resistance.H. Czosnek, ed. Springer, The Netherlands.

Antignus, Y. 2010. Optical manipulation for control of Bemisia tabaci; and its vectored viruses in the greenhouse and open field. Pages 349-356 in: Bemisia: Bionomics and Management of a Global Pest. P. A. Stansly and S. E. Naranjo, eds. Springer, The Netherlands.

Antignus, Y. 2014. Management of air-borne viruses by optical barriers in protected agriculture and open-field crops. Adv. Virus Res. 90:1-33.

Benhamou, N., and Belanger, R. R. 1998. Benzothiadiazole-mediated induced resistance to Fusarium oxysporum f. sp. radicis-lycopersici in tomato. Plant Physiol. 118:1203-1212.

Boughton, A., Hoover, K., and Felton, G. 2006. Impact of chemical elicitor applications on greenhouse tomato plants and population growth of the green peach aphid, Myzus persicae. Entomol. Exp. Appl. 120:175-188.

Brown, J., Zerbini, F. M., Navas-Castillo, J., Moriones, E., Ramos-Sobrinho, R. Silva, J., Fiallo-Olivé, E., Briddon, R., Hernandez-Zepeda, C., Idris, A. Malathi, V. G., Martin, D., Rivera-Bustamante, R., Ueda, S., and Varsani, A. 2015. Revision of begomovirus taxonomy based on pairwise sequence comparisons. Arch. Virol. 160:1593-1619.

Chiel, E., Messika, Y., Steinberg, S., and Antignus, Y. 2006. The effect of UVabsorbing plastic sheet on the attraction and host location ability of three parasitoids: Aphidius colemani, Diglyphus isaea and Eretmocerus mundus. BioControl 51:65-78.

Chivasa, S., Murphy, A. M., Naylor, M., and Carr, J. P. 1997. Salicylic acid interferes with tobacco mosaic virus replication via a novel salicylhydroxamic acid-sensitive mechanism. Plant Cell 9:547-557.

Cipollini, D., Purrington, C. B., and Bergelson, J. 2003. Costs of induced responses in plants. Basic Appl. Ecol. 4:79-89.

Cohen, S., and Antignus, Y. 1994. Tomato yellow leaf curl virus, a whitefly-borne geminivirus of tomatoes. Adv. Dis. Vector Res. 10:259-288.

Costa, H. S., Robb, K. L., and Wilen, C. A. 2002. Field trials measuring the effects of ultraviolet-absorbing greenhouse plastic films on insect populations. J. Econ. Entomol. 95:113-120.

Díaz, B. M., and Fereres, A. 2007. Ultraviolet-blocking materials as a physical barrier to control insect pests and plant pathogens in protected crops. Pest. Technol. 1:85-95. 
Doukas, D., and Payne, C. C. 2007. Greenhouse whitefly (Homoptera: Aleyrodidae) dispersal under different UV-light environments. J. Econ. Entomol. 100:389-397.

Dyer, A. G., and Chittka, L. 2004. Bumblebee search time without ultraviolet light. J. Exp. Biol. 207:1683-1688.

Eikemo, H., Stensvand, A., and Tronsmo, A. M. 2003. Induced resistance as a possible means to control diseases of strawberry caused by Phytophthora spp. Plant Dis. 87:345-350.

Fabre, F., Rousseau, E., Mailleret, L., and Moury, B. 2012. Durable strategies to deploy plant resistance in agricultural landscapes. New Phytol. 193:1064-1075.

Fanigliulo, A., Ferrara, L., Caligiuri, G., Comes, S., Momol, M. T., Olson, S. M., and Crescenzi, A. 2006. Integrated management of TYLCV/TYLCSV on greenhouse hydroponic tomatoes in Southern Italy. Comm. Appl. Biol. Sci. 71:1245-1249

Faoro, F., and Gozzo, F. 2015. Is modulating virus virulence by induced systemic resistance realistic? Plant Sci. 234:1-13.

Friedrich, L., Lawton, K., Ruess, W., Masner, P., Specker, N., Rella, M. G., Meier, B., Dincher, S., Staub, T., Uknes, S., Métraux, J.-P., Kessmann, H., and Ryals, J. 1996. A benzothiadiazole derivative induces systemic acquired resistance in tobacco. Plant J. 10:61-70.

Gorlach, J., Volrath, S., KnaufBeiter, G., Hengy, G., Beckhove, U., Kogel, K. H., Oostendorp, M., Staub, T., Ward, E., Kessmann, H., and Ryals, J. 1996. Benzothiadiazole, a novel class of inducers of systemic acquired resistance, activates gene expression and disease resistance in wheat. Plant Cell 8:629-643.

Hanssen, I. M., Lapidot, M., and Thomma, B. P. H. J. 2010.Emerging viral diseases of tomato crops. Mol. Plant-Microbe Interact. 23:539-548.

Herman, M. A. B., Davidson, J. K., and Smart, C. D. 2008. Induction of plant defense gene expression by plant activators and Pseudomonas syringae pv. tomato in greenhouse-grown tomatoes. Phytopathology 98:1226-1232.

Horowitz, R., Denholm, I., and Morin, S. 2007. Resistance to insecticides in the TYLCV vector Bemisia tabaci. Pages 305-325 in: Tomato Yellow Leaf Curl Virus Disease Management, Molecular Biology, Breeding for Resistance. $\mathrm{H}$. Czosnek, ed. Springer, Netherlands.

Huang, C. H., Vallad, G. E., Zhang, S., Wen, A., Balogh, B., Figueiredo, J. F., Behlau, F., Jones, J. B., Momol, M. T., and Olson, S. M. 2012. Effect of application frequency and reduced rates of acibenzolar-S-methyl on the field efficacy of induced resistance against bacterial spot on tomato. Plant Dis. 96: 221-227.

Ji, L. H., and Ding, S. W. 2001. The suppressor of transgene RNA silencing encoded by Cucumber mosaic virus interferes with salicylic acid-mediated virus resistance. Mol. Plant-Microbe Interact. 14:715-724.

Katz, V. A., Thulke, O. U., and Conrath, U. 1998. A benzothiadiazole primes parsley cells for augmented elicitation of defense responses. Plant Physiol. 117:1333-1339.

Kumar, P., and Poehling, H. M. 2006. UV-blocking plastic films and nets influence vectors and virus transmission on greenhouse tomatoes in the humid tropics. Environ. Entomol. 35:1069-1082.

Lapidot, M., Legg, J. P., Wintermantel, W. M., and Polston, J. E. 2014. Management of whitefly-transmitted viruses in open-field production systems. Adv. Virus Res. 90:147-206.

Lawton, K. A., Friedrich, L., Hunt, M., Weymann, K., Delaney, T., Kessmann, H., Staub, T., and Ryals, J. 1996. Benzothiadiazole induces disease resistance in Arabidopsis by activation of the systemic acquired resistance signal transduction pathway. Plant J. 10:71-82.

Lefeuvre, P., Martin, D. P., Harkins, G., Lemey, P., Gray, A. J. A., Meredith, S., Lakay, F., Monjane, A., Lett, J. M., Varsani, A., and Heydarnejad, J. 2010. The spread of tomato yellow leaf curl virus from the Middle East to the world. PLoS Pathog 6:e1001164.

Legarrea, S., Weintraub, P. G., Plaza, M., Viñuela, E., and Fereres, A. 2012. Dispersal of aphids, whiteflies and their natural enemies under photoselective nets. BioControl 57:523-532

Malolepsza, U. 2006. Induction of disease resistance by acibenzolar-S-methyl and o-hydroxyethylorutin against Botrytis cinerea in tomato plants. Crop Prot. 25: 956-962.

Mandal, B., Mandal, S., Csinos, A. S., Martinez, N., Culbreath, A. K., and Pappu, H. R. 2008. Biological and molecular analyses of the acibenzolar-S-methylinduced systemic acquired resistance in flue-cured tobacco against Tomato spotted wilt virus. Phytopathology 98:196-204.

Michelson, I., Zamir, D., and Czosnek, H. 1994. Accumulation and translocation of tomato yellow leaf curl virus (TYLCV) in a Lycopersicon esculentum breeding line containing the $L$. chilense TYLCV tolerance gene $T y-1$. Phytopathology 84:928-933.

Momol, M. T., Olson, S. M., Funderburk, J. E., Stavisky, J., and Marois, J. J. 2004. Integrated management of tomato spotted wilt on field-grown tomatoes. Plant Dis. 88:882-890.

Moriones, E., and Navas-Castillo, J. 2010. Tomato yellow leaf curl disease epidemics. Pages 259-282 in: Bemisia: Bionomics and Management of a Global Pest. P. A. Stansly and S. E. Naranjo, eds. Springer, The Netherlands.
Moriones, E., Navas-Castillo, J., and Diaz-Pendon, J. A. 2011. Emergence of begomovirus diseases. Pages 301-320 in: Recent Advances in Plant Virology. C. Caranta, M. A. Aranda, M. Tepfer, J. J. López-Moya, eds. Caister Academic Press, U.K.

Moury, B., Fereres, A., García-Arenal, F., and Lecoq, H. 2011. Sustainable management of plant resistance to viruses. Pages 219-236 in: Recent Advances in Plant Virology. C. Caranta, M. A. Aranda, M. Tepfer, J. J. López-Moya, eds. Caister Academic Press, U.K.

Mundt, C. C., Cowger, C., and Garrett, K. A. 2002. Relevance of integrated disease management to resistance durability. Euphytica 124:245-252.

Murphy, A. M., and Carr, J. P. 2002. Salicylic acid has cell-specific effects on Tobacco mosaic virus replication and cell-to-cell movement. Plant Physiol. 128:552-563

Murphy, A. M., Chivasa, S., Singh, D. P., and Carr, J. P. 1999. Salicylic acidinduced resistance to viruses and other pathogens: A parting of the ways? Trends Plant Sci. 4:155-160.

Mutwiwa, U. N., Borgemeister, C., von Elsner, B., and Tantau, H. J. 2005. Effects of UV-absorbing plastic films on greenhouse whitefly (Homoptera: Aleyrodidae). J. Econ. Entomol. 98:1221-1228.

Navas-Castillo, J., Sánchez-Campos, S., Díaz, J. A., Sáez-Alonso, E., and Moriones, E. 1999. Tomato yellow leaf curl virus-Is causes a novel disease of common bean and severe epidemics in tomato in Spain. Plant Dis. 83: 29-32.

Naylor, M., Murphy, A. M., Berry, J. O., and Carr, J. P. 1998. Salicylic acid can induce resistance to plant virus movement. Mol. Plant-Microbe Interact. 11: 860-868.

Nombela, G., Pascual, S., Avilés, M., Guillard, E., and Muñíz, M. 2005. Benzothiadiazole induces local resistance to Bemisia tabaci (Hemiptera: Aleyrodidae) in tomato plants. J. Econ. Entomol. 98:2266-2271.

Oostendorp, M., Kunz, W., Dietrich, B., and Staub, T. 2001. Induced disease resistance in plants by chemicals. Eur. J. Plant Pathol. 107:19-28.

Palukaitis, P., Yoon, J.-Y., Choi, S.-K., and Carr, J. P. 2017. Manipulation of induced resistance to viruses. Curr. Opin. Virol. 26:141-148.

Polston, J., and Lapidot, M. 2007. Management of Tomato yellow leaf curl virus: US and Israel Perspectives. Pages 251-262 in: Tomato Yellow Leaf Curl Virus Disease Management, Molecular Biology, Breeding for Resistance. H. Czosnek, ed. Springer, Netherlands.

Pradhanang, P. M., Ji, P., Momol, M. T., Olson, S. M., Mayfield, J. L., and Jones, J. B. 2005. Application of acibenzolar-S-methyl enhances host resistance in tomato against Ralstonia solanacearum. Plant Dis. 89:989-993.

Radhakrishnan, N., Alphonse, A. J., and Balasubramanian, R. 2011. Effect of Acibenzolar-S-methyl (ASM) pre-treatment in inducing resistance against Pythium aphanidermatum infection in Curcuma longa. Crop Prot. 30:24-32.

Riley, D. G., Joseph, S. V., and Srinivasan, R. 2012. Reflective mulch and acibenzolar-S-methyl treatments relative to thrips (Thysanoptera: Thripidae) and tomato spotted wilt virus incidence in tomato. J. Econ. Entomol. 105: 1302-1310.

Robert-Seilaniantz, A., Grant, M., and Jones, J. D. G. 2011. Hormone crosstalk in plant disease and defense: More than just jasmonate-salycilate antagonism. Annu. Rev. Phytopathol. 49:317-343.

Scholthof, K. B., Adkins, S., Czosnek, H., Palukaitis, P., Jacquot, E., Hohn, T., Hohn, B., Saunders, K., Candresse, T., Ahlquist, P., Hemenway, C., and Foster, G. D. 2011. Top 10 plant viruses in molecular plant pathology. Mol. Plant Pathol. 12:938-954.

Shang, J., Xi, D. H., Xu, F., Wang, S. D., Cao, S., Xu, M. Y., Zhao, P. P., Wang, J. H., Jia, S. D., Zhang, Z. W., Yuan, S., and Lin, H. H. 2011. A broad-spectrum, efficient and nontransgenic approach to control plant viruses by application of salicylic acid and jasmonic acid. Planta 233:299-308

Shi, X., Pan, H., Xie, W., Wu, Q., Wang, S., Liu, Y., Fang, Y., Chen, G., Gao, X., and Zhang, Y. 2013. Plant virus differentially alters the plant's defense response to its closely related vectors. PLoS One 8:e83520.

Sirigu, A., Nannini, M., Chessa, F., and Crescenzi, A. 2009. Integrated approach to TYLCD management in Sardinia (Italy). Comm. Appl. Biol. Sci. 74:809-819.

Sticher, L., Mauch-Mani, B., and Metraux, J. P. 1997. Systemic acquired resistance. Annu. Rev. Phytopathol. 35:235-270.

Takeshita, M., Okuda, M., Okuda, S., Hyodo, A., Hamano, K., Furuya, N., and Tsuchiya, K. 2013. Induction of antiviral responses by acibenzolar-S-methyl against Cucurbit chlorotic yellows virus in melon. Phytopathology 103 960-965.

Vallad, G. E., and Goodman, R. M. 2004. Systemic acquired resistance and induced systemic resistance in conventional agriculture. Crop Sci. 44:1920-1934.

Varma, A., Mandal, B., and Singh, M. K. 2011. Global emergence and spread of whitefly Bemisia tabaci-transmitted geminiviruses. Pages 205-292 in: The Whitefly, Bemisia tabaci (Homoptera: Aleyrodidae) Interaction with GeminivirusInfected Host Plants. W. M. O. Thompson, ed. Springer, The Netherlands.

Zhu, F., Xi, D. H., Yuan, S., Xu, F., Zhang, D. W., and Lin, H. H. 2014. Salicylic acid and jasmonic acid are essential for systemic resistance against Tobacco mosaic virus in Nicotiana benthamiana. Mol. Plant-Microbe Interact. 27: 567-577. 